\title{
Epiphytic biomass of a tropical montane forest varies with topography
}

\author{
F. A. Werner*,1, J. Homeier†, M. Oeskerł and J. Boy§ \\ * Functional Ecology, Institute of Biology and Environmental Sciences, University of Oldenburg, Carl-von-Ossietzkystraße 9-11, 26111 Oldenburg, Germany \\ $\dagger$ Plant Ecology, Institute of Plant Sciences, Untere Karspüle 2, University of Göttingen, 37073 Göttingen, Germany \\ $\ddagger$ Institute of Botany (210), University of Hohenheim, Garbenstraße 30, 70593 Stuttgart, Germany \\ $\S$ Institute of Soil Science, University of Hannover, Herrenhäuser Straße 2, 30419 Hannover, Germany \\ (Accepted 22 September 2011)
}

\begin{abstract}
The spatial heterogeneity of tropical forest epiphytes has rarely been quantified in terms of biomass. In particular, the effect of topographic variation on epiphyte biomass is poorly known, although forests on ridges and ravines can differ drastically in stature and exposure. In an Ecuadorian lower montane forest we quantified epiphytic biomass along two gradients: (1) the twig-branch-trunk trajectory, and (2) the ridge-ravine gradient. Twenty-one trees were sampled in each of three forest types (ridge, slope, ravine positions). Their epiphytic biomass was extrapolated to stand level based on basal area-epiphyte load relationships, with tree basal areas taken from six plots of $400 \mathrm{~m}^{2}$ each per forest type. Our results document the successional addition and partial replacement of lichens by bryophytes, angiosperms and finally dead organic matter along the twig-branch-trunk trajectory. Despite having the highest tree basal area, total epiphytic biomass (mean \pm SD) of ravine forest was significantly lower $\left(2.6 \pm 0.7 \mathrm{Mg} \mathrm{ha}^{-1}\right)$ than in mid-slope forest $\left(6.3 \pm 1.1 \mathrm{Mg} \mathrm{ha}^{-1}\right)$ and ridge forest $\left(4.4 \pm 1.6 \mathrm{Mg} \mathrm{ha}^{-1}\right)$, whereas maximum bryophyte water storage capacity was significantly higher. We attribute this pattern to differences in forest dynamics, stand structure and microclimate. Although our study could not differentiate between direct effects of slope position (nutrient availability, mesoclimate) and indirect effects (stand structure and dynamics), it provides evidence that fine-scale topography needs to be taken into account when extrapolating epiphytic biomass and related matter fluxes from stand-level data to the regional scale.
\end{abstract}

Key Words: carbon storage, crown humus, dead organic matter, Ecuador, epiphytes, maximum water storage capacity, succession, topographic heterogeneity

\section{INTRODUCTION}

Epiphytes can strongly increase the retention of atmospheric water and mineral nutrients by tropical forests (Bruijnzeel et al. 2011, Cavelier et al. 1997, Holwerda et al. 2010, Tobón et al. 2010, Umana \& Wanek 2010). Epiphytic biomass can account for over $80 \%$ of non-woody canopy biomass (Nadkarni et al. 2004) and store up to $50 \mathrm{Mg} \mathrm{ha}^{-1}$ of water (Pócs 1980). By increasing the spatial heterogeneity of canopy throughfall, epiphytes may even drive niche availability and recruitment of terrestrial plants (Oesker et al. 2010, Zimmermann et al. 2007).

Moist-forest epiphytes typically show marked succession as primary twigs grow in diameter and age, with lichens pioneering before bryophytes become dominant,

\footnotetext{
${ }^{1}$ Corresponding author. Email: florianwerner@yahoo.com
}

which in turn form substrates vital for the establishment of most pteridophytes and angiosperms (Dudgeon 1923, Zotz \& Vollrath 2003). While these successional changes along the entire twig-branch trajectory have often been addressed in terms of diversity, they have rarely been quantified with respect to biomass (but see Hsu et al. 2002, Nadkarni et al. 2004). At the stand level, epiphytes attain their greatest diversity and abundance in wet tropical montane forests, where moderate temperatures coupled with constantly high humidity favour the growth of epiphytes and the accumulation of dead organic matter (Birch \& Friend 1956, Gentry \& Dodson 1987, Kreft et al. 2004). However, even among moist montane forests, reported epiphytic biomass ranges from 2 (Pócs 1980) to as much as $44 \mathrm{Mg}$ of biomass ha ${ }^{-1}$ (Hofstede et al. 1993; see also Köhler et al. 2007, Wolf 1995). This variability is not well understood, and large-scale geographical patterns of epiphytic biomass remain unclear. It is also uncertain to what extent the amount and composition of 
epiphytic biomass may vary with topography at the local scale.

In many tropical mountains, forest structure changes strikingly from ravines and valley bottoms to ridges (Homeier et al. 2010, Takuya et al. 2002). This physiognomic divergence is related to several major environmental gradients (e.g. soil nutrient status, wind turbulence; Bellingham \& Tanner 2000, Oesker et al. 2008). Although epiphytes are not directly linked to soil characteristics such as water and nutrient availability, they are linked indirectly via throughfall and litter quality, stand dynamics and microclimate. Because epiphytic biomass accumulates slowly (Nadkarni 2000), high tree turnover rates should limit the accumulation of large epiphytic biomass (Tanner 1980). Stand structure (e.g. canopy height, leaf area index (LAI)) affects both quantity and quality of epiphyte substrates and modifies wind penetration, air humidity and the availability of light (Motzer 2005). Forest microclimate is also affected by variation in above-canopy climate (mesoclimate) that results from greater exposure of ridges to wind, fog and solar radiation as compared with sheltered ravines.

The purpose of this paper is to determine the spatial distribution of epiphytic biomass, its key components (lichens, bryophytes, pteridophytes, angiosperms, dead organic matter) and their contribution to stand-level biomass at a lower montane tropical Andean site. In particular, our study compares three adjacent forest types along a topographic gradient. Stand height, LAI and tree turnover in this forest area decline markedly from ravines towards ridges (Homeier et al. 2010). Since high light availability and low tree turnover should promote the accumulation of epiphytic matter, we expected biomass to be greatest along ridges.

\section{METHODS}

\section{Study site}

Field work was done in old-growth montane moist forest at Reserva Biológica San Francisco (RBSF; c. 1000 ha, ranging from $1800-3150 \mathrm{~m}$ asl) in Zamora-Chinchipe Province, south-eastEcuador $\left(3^{\circ} 58^{\prime} \mathrm{S}\right.$, $\left.79^{\circ} 04^{\prime} \mathrm{W}\right)$. Precipitation at $1960 \mathrm{~m}$ averages $2080 \mathrm{~mm}$ $\mathrm{y}^{-1}$, mean temperature and air humidity are $15.5^{\circ} \mathrm{C}$ and $86 \%$, respectively. Fog is infrequent. A gentle dry season averaging 1 mo with $<100 \mathrm{~mm}$ of rain usually extends from $c$. October to February (see Bendix et al. 2008, Emck 2007 for details).

The area is highly diverse in epiphytes, with some 1250 species of epiphytic lichen, bryophyte and vascular plant recorded for the RBSF (Liede \& Breckle 2007). Ravine forest has a dense canopy of 20-25 m in height and only shares a small percentage of tree species with ridge forest, which is relatively open and stunted (8-12 m tall). Midslope forest is intermediate in terms of tree species composition and structure (canopy height 12-18 m). Concurrent with soil nutrient concentrations, tree basal area increment and turnover decrease strongly from ravines to ridges (Homeier et al. 2008, 2010; Wilcke et al. 2008).

\section{Sampling and analysis}

We sampled epiphytic biomass from 63 trees which were selectively felled in the course of an experiment on sustainable forest management in June-July 2004 (Günter et al. 2008) in two neighbouring microcatchments. Fifteen canopy and subcanopy trees of various size classes were randomly selected in ravine forest (2000-2100 m asl), mid-slope forest (2050-2150 $\mathrm{m}$ ) and ridge-top forest (2100-2200 m). Six additional understorey treelets per forest type (mostly saplings; Appendix 1) were sampled exclusively for the projection of epiphytic biomass to area. Trees that had suffered damage from felling were omitted. Extensive data on the local tree species composition (Homeier et al. 2010) suggest that our samples were representative of the local tree communities (Appendix 1).

We distinguished six substrate classes: twigs (0-2 $\mathrm{cm}$ diameter), thin branches $(>2-5 \mathrm{~cm})$, medium-sized branches $(>5-10 \mathrm{~cm})$, large branches $(>10-20 \mathrm{~cm})$, major limbs $(>20 \mathrm{~cm})$ and trunks. Sampled substrate sections ranged from $10 \mathrm{~cm}$ (trunks and larger branches) to $100 \mathrm{~cm}$ (twigs) in length. Where applicable, we randomly took biomass samples from all diameter classes of three major branches per tree (one from upper, midand lower canopy each). In trunks, one sample was taken from base, mid-section and upper section each. We visually estimated the total length of twigs/branches within each branch class of a sampling tree to allow for an extrapolation of total biomass per tree, while trunk lengths were measured with a tape.

In total, 710 samples were taken, transferred in plastic bags to the field station Estación Científica San Francisco, and separated in the laboratory. We distinguished between bryophytes, macrolichens (foliose and fruticose growth types), pteridophytes, angiosperms and dead organic (biological) matter (DBM henceforth; canopy humus and epiphyte litter). Samples were oven-dried to constant weight at $70{ }^{\circ} \mathrm{C}$ and weighed with an electronic balance (Navigator, Ohaus, Pine Brook, NJ, USA). In order to project our data to forest area, we measured the diameter at breast height (dbh) for all tree trunks of dbh $\geq 5 \mathrm{~cm}$ in 18 plots of $20 \times 20 \mathrm{~m}$, six each in ravine, slope and ridge position. These plots were set up in mature forest stands at 1960-2210 m within RBSF.

Prior to analysis we divided raw sample dry weights by sample area (cylinder length $\times$ perimeter) and averaged 
Table 1. Epiphytic biomass ( $\mathrm{g} \mathrm{m}^{-2}$ substrate surface) in three adjacent montane forest types in south-east Ecuador. Given is the mean $\pm \mathrm{SE}$ (median). Biomass data for branches is ordered by diameter class, while data for trunks are treated as 'trunks' irrespective of diameter. Different superscript letters mark parameters showing significant differences $(\mathrm{P}<0.05$; Scheffé post hoc tests following ANCOVA) between forest types after false discovery rate correction. Note that branches $>20 \mathrm{~cm}$ diameter were not tested for significant differences.

\begin{tabular}{|c|c|c|c|c|c|c|c|}
\hline Substrate diam. $(\mathrm{cm})$ & $\mathrm{n}$ & Lichens & Bryophytes & Pteridophytes & Angiosperms & $\begin{array}{c}\text { Dead organic } \\
\text { matter }\end{array}$ & $\begin{array}{c}\text { Total epiphytic } \\
\text { biomass }\end{array}$ \\
\hline \multicolumn{8}{|l|}{ Ravine forest } \\
\hline $0-2$ & 15 & $19 \pm 6(12)$ & $19 \pm 6(8)$ & $0.1 \pm 0.1(0.0)$ & $4 \pm 2(0.0)$ & $3 \pm 2(0.0)$ & $45^{\mathrm{a}} \pm 12(33)$ \\
\hline $2-5$ & 15 & $61 \pm 18(38)$ & $57 \pm 12(52)$ & $5 \pm 3(0.0)$ & $26 \pm 15(2)$ & $6^{a} \pm 3(2)$ & $155 \pm 28(146)$ \\
\hline $5-10$ & 15 & $28 \pm 7(22)$ & $72 \pm 13(50)$ & $6 \pm 3(0.0)$ & $73 \pm 43(5)$ & $39^{a} \pm 30(6)$ & $216 \pm 68(132)$ \\
\hline $10-15$ & 12 & $32 \pm 11(20)$ & $121 \pm 47(68)$ & $35 \pm 17(9)$ & $211 \pm 155(32)$ & $191 \pm 114(10)$ & $591 \pm 275(234)$ \\
\hline$>20$ & 5 & $11 \pm 5(11)$ & $106 \pm 35(64)$ & $2 \pm 1(2)$ & $70 \pm 52(7)$ & $90 \pm 45(49)$ & $279 \pm 120(189)$ \\
\hline Trunk & 15 & $9^{\mathrm{ab}} \pm 3(4)$ & $44^{\mathrm{a}} \pm 11(28)$ & $3 \pm 1(0.2)$ & $30^{\mathrm{a}} \pm 11(10)$ & $34^{\mathrm{a}} \pm 22(6)$ & $120 \pm 33(85)$ \\
\hline \multicolumn{8}{|l|}{ Slope forest } \\
\hline $0-2$ & 15 & $24 \pm 7(13)$ & $18 \pm 8(6)$ & $7 \pm 5(0.0)$ & $18 \pm 7(6)$ & $13 \pm 6(6)$ & $79^{b} \pm 21(57)$ \\
\hline $2-5$ & 15 & $59 \pm 21(30)$ & $71 \pm 25(24)$ & $3 \pm 2(0.0)$ & $52 \pm 20(12)$ & $29^{b} \pm 10(16)$ & $214 \pm 45(142)$ \\
\hline $5-10$ & 14 & $47 \pm 21(8)$ & $95 \pm 23(58)$ & $8 \pm 5(0.1)$ & $137 \pm 40(70)$ & $68^{\mathrm{ab}} \pm 18(47)$ & $354 \pm 62(405)$ \\
\hline $10-15$ & 7 & $20 \pm 11(6)$ & $58 \pm 25(54)$ & $8 \pm 5(4)$ & $178 \pm 69(85)$ & $118 \pm 48(43)$ & $381 \pm 135(232)$ \\
\hline$>20$ & 3 & $11 \pm 9(3)$ & $16 \pm 14(3)$ & $1 \pm 1(0.0)$ & $110 \pm 109(3)$ & $144 \pm 123(41)$ & $281 \pm 245(74)$ \\
\hline Trunk & 15 & $3^{\mathrm{a}} \pm 2(0.4)$ & $52^{\mathrm{ab}} \pm 12(51)$ & $34 \pm 13(18)$ & $237^{\mathrm{ab}} \pm 72(160)$ & $631^{\mathrm{b}} \pm 250(210)$ & $958 \pm 311(517)$ \\
\hline \multicolumn{8}{|l|}{ Ridge forest } \\
\hline $0-2$ & 15 & $24 \pm 7(16)$ & $14 b \pm 9(1)$ & $1 \pm 1(0.0)$ & $13 \pm 7(0.2)$ & $18 \pm 13(1)$ & $70^{\mathrm{b}} \pm 34(17)$ \\
\hline $2-5$ & 15 & $58 \pm 14(60)$ & $58 \pm 25(22)$ & $25 \pm 18(0.0)$ & $60 \pm 24(17)$ & $43^{b} \pm 18(14)$ & $243 \pm 69(92)$ \\
\hline $5-10$ & 13 & $33 \pm 7(28)$ & $95 \pm 21(58)$ & $24 \pm 11(3)$ & $337 \pm 221(59)$ & $115^{\mathrm{b}} \pm 50(77)$ & $604 \pm 282(425)$ \\
\hline $10-15$ & 6 & $20 \pm 6(16)$ & $170 \pm 38(152)$ & $59 \pm 56(2)$ & $742 \pm 365(511)$ & $536 \pm 202(358)$ & $1527 \pm 504(1233)$ \\
\hline$>20$ & 0 & $- \pm-(-)$ & $- \pm-(-)$ & $- \pm-(-)$ & $- \pm-(-)$ & $- \pm-(-)$ & $- \pm-(-)$ \\
\hline Trunk & 15 & $16^{\mathrm{b}} \pm 4(9)$ & $99^{b} \pm 16(61)$ & $30 \pm 9(18)$ & $490^{b} \pm 318(66)$ & $431^{b} \pm 255(108)$ & $1065 \pm 425(423)$ \\
\hline
\end{tabular}

all replicates of a given substrate class of individual trees. We did not distinguish between regular branch sections and forks. Comparisons between forest types were done through ANCOVA with mean substrate diameter as a covariate and subsequent correction for false discovery rate (FDR; Benjamini \& Hochberg 1995). We calculated the epiphytic biomass of each sampled tree by multiplying mean biomass values of each substrate class by the respective surface areas of the tree. For every forest type we then fitted linear functions with zero intercept to the relationship between tree basal area and individual epiphytic biomass components (lichens, bryophytes, vascular plants, DBM) of a given tree (Wolf et al. 2009). Because pteridophytes yielded poor fits they were lumped with angiosperms for this purpose. These linear functions allowed us to project our biomass data to forest area by applying them to quantitative size class distributions of each plot after correction for slope inclination.

We used wet-dry ratios ((wet weight - dry weight)/dry weight) of bryophyte weights provided by Kürschner \& Parolly (2004) for the three forest types under study (ravine forest: 7.04; slope forest: 6.89; ridge forest: 5.27) to project the water storage capacity of epiphytic bryophytes to forest area. Using one-way ANOVA we compared forest types in terms of bryophyte water storage capacity. Statistics were done with Statistica 8 (ANOVA; Statsoft, Tulsa, OK, USA) and R 2.13.0 (regression analysis; R Development Core Team, Vienna, http://www.R-project.org/).

\section{RESULTS}

Total biomass density consistently increased with branch diameter from the outer to the inner crown. This pattern was apparent for all individual components except for lichens, which instead peaked on thin branches of $2-$ $5 \mathrm{~cm}$ diameter. Highest biomass density of angiosperms and DBM was found on branches of 10-20 cm diameter (ravine forest) or on trunks (slope and ridge forest; Table 1). In relative terms, the contribution of lichens to total biomass was greatest on twigs $\leq 2 \mathrm{~cm}$, bryophytes peaked on thin branches of $2-5 \mathrm{~cm}$, angiosperms on branches of $10-20 \mathrm{~cm}$ diameter, and DBM on trunks (Figure 1).

Epiphytic biomass tended to be highest in ridge forest and lowest in ravine forest and slope forest, but patterns were variable among substrate classes with regard to several biomass components. Generally, greatest differences between forest types were found for trunks, which showed significantly different biomass densities of lichens, bryophytes, angiosperms and DBM (Table 1). Related to high variability, branches only exhibited statistically significant differences in terms of DBM (branch diameters 2-5 and 5-10 cm) and total epiphytic biomass (twigs $<2 \mathrm{~cm}$ ).

In all forest types, total epiphytic biomass and most of its individual components (except pteridophytes in slope forest) were closely related to tree size. A linear model provided a better fit to the relationship of epiphytic 


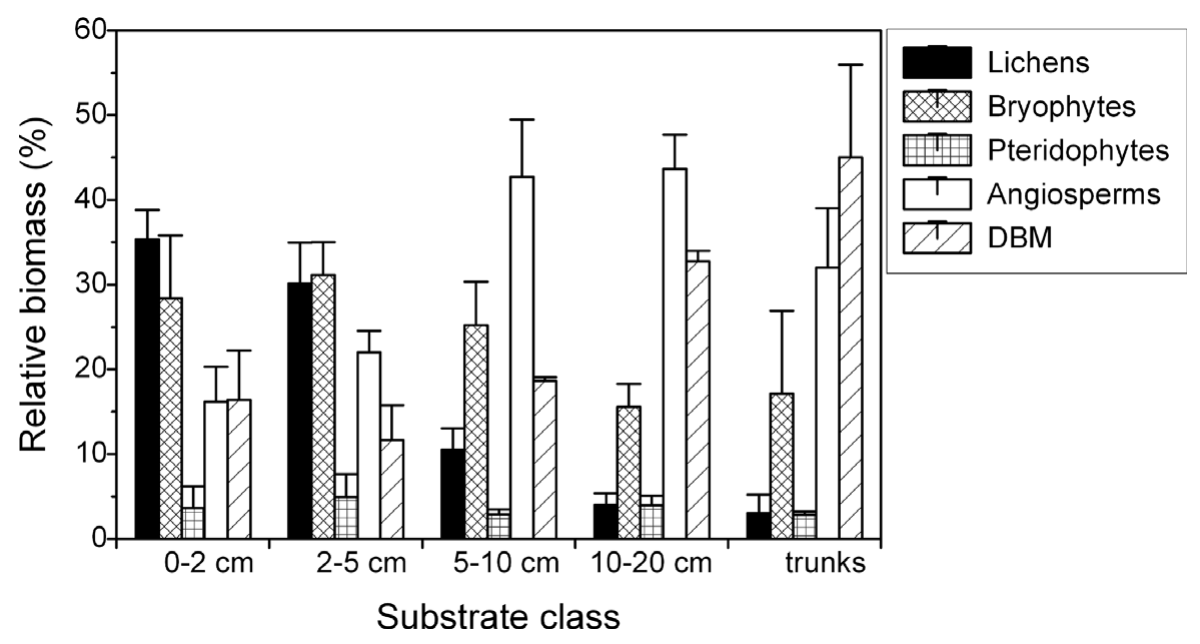

Figure 1. The relative contribution of individual biomass components (macrolichens, bryophytes, pteridophytes, angiosperms, dead organic matter (DBM)) to total epiphytic biomass in lower montane forest, south-east Ecuador. Shown are mean \pm SE of three adjacent forest types in ridge, slope and ravine position. Biomass data for branches is ordered by diameter class, data for trunks are treated as 'trunks' irrespective of diameter. Absolute values are shown in Table 1.

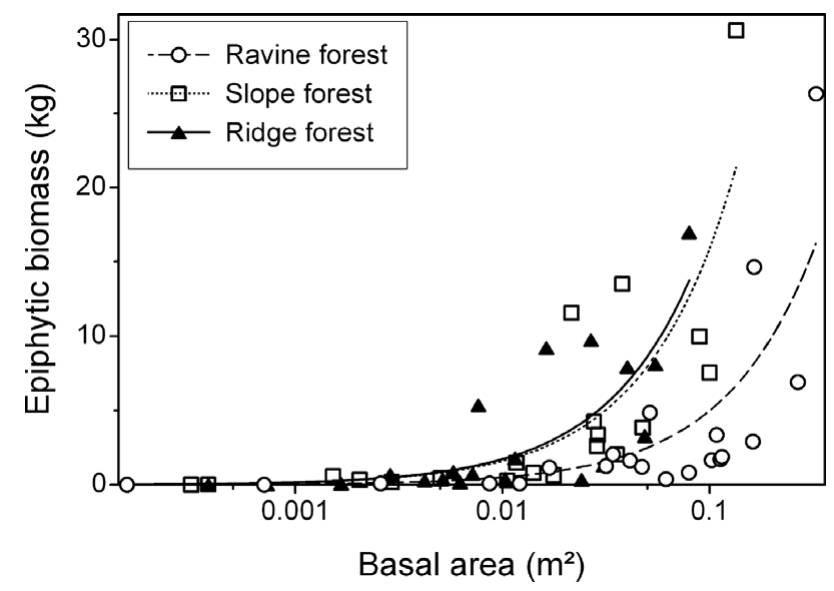

Figure 2. The relationship of total epiphytic biomass (macrolichens, bryophytes, pteridophytes, angiosperms and dead organic matter) in relation with tree size (basal area) in three adjacent lower montane forest types in south-eastern Ecuador $(\mathrm{n}=21$ trees). Linear regression equations are given in Table 2.

biomass with tree basal area (Figure 2; Table 2) than with dbh. Extrapolation to stand level yielded total epiphytic biomass values (mean $\pm \mathrm{SD}$ ) of $2.6 \pm 0.7 \mathrm{Mg} \mathrm{ha}^{-1}$ for ravine forest, $6.3 \pm 1.1 \mathrm{Mg} \mathrm{ha}^{-1}$ for slope forest and $4.4 \pm 1.6 \mathrm{Mg} \mathrm{ha}^{-1}$ for ridge forest (Table 3). These differences were significant (one-way ANOVA $\mathrm{F}_{2,15}=$ 14.7, $\mathrm{P}=0.0002$ ), with total biomass in ravine forest being lower than in slope forest (Scheffé post hoc test: $\mathrm{P}=$ $0.0003)$ and in ridge forest $(\mathrm{P}=0.04)$, whereas slope and ridge forest did not differ significantly $(\mathrm{P}=0.06)$. While some individual biomass components (lichens, angiosperms, DBM) also showed highest biomass in slope forest, bryophytes tended to have somewhat higher mean biomass in ravines, and pteridophytes on ridges (Table 3).
Maximum water storage capacity of bryophytes was $0.52 \pm 0.14 \mathrm{~mm}$ in ravines (mean $\pm \mathrm{SD}$ ), $0.36 \pm$ $0.06 \mathrm{~mm}$ on slopes and $0.30 \pm 0.10 \mathrm{~mm}$ along ridges. These differences were statistically significant (ANOVA $\mathrm{F}_{2,15}=9.3, \mathrm{P}=0.002$ ) with water storage capacity being significantly higher in ravine forest than in forest on slopes (Scheffé test: $\mathrm{P}=0.02)$ and ridges $(\mathrm{P}=0.003)$.

\section{DISCUSSION}

\section{Local sources of variability in epiphytic biomass}

The present study considers three sources of variability for the quality and quantity of epiphytic biomass: substrate diameter (within-tree variability), tree size and topographic position. Our results show that all three spatial or spatio-temporal levels add substantially to the high spatial heterogeneity of epiphyte distribution in the study area.

Composition and overall quantity of epiphytic biomass were closely related to the diameter (and thus age) of substrate classes within a given tree, tree size and forest type. Our study thus corroborates the successional addition and (partial) replacement of lichens by bryophytes, pteridophytes, angiosperms and finally DBM along the twig-branch-trunk trajectory (Freiberg \& Freiberg 2000, Hsu et al. 2002, Köhler et al. 2007). While angiosperms and DBM require a long time to build up and greatly benefit from the presence of bryophytes as substrates (Zotz \& Vollrath 2003), many lichens are successful primary colonizers that thrive under the strong exposure to light and desiccation that characterize the twigs of the outer canopy (Sipman \& Harris 1989). Overall, biomass density was rather low compared with 
Table 2. Coefficients from linear regression $(\mathrm{y}=\mathrm{mx})$ of epiphytic biomass versus tree basal area in three adjacent montane forest types in south-east Ecuador. All regressions yielded significant relationships $(\mathrm{P}<0.001)$.

\begin{tabular}{|c|c|c|c|c|c|c|c|c|c|c|}
\hline & \multicolumn{2}{|c|}{ Lichens } & \multicolumn{2}{|c|}{ Bryophytes } & \multicolumn{2}{|c|}{$\begin{array}{c}\text { Vascular } \\
\text { plants }\end{array}$} & \multicolumn{2}{|c|}{$\begin{array}{l}\text { Dead organic } \\
\text { matter }\end{array}$} & \multicolumn{2}{|c|}{ Total biomass } \\
\hline & $\mathrm{R}^{2}$ & $\bar{m}$ & $\mathrm{R}^{2}$ & $\mathrm{~m}$ & $\mathrm{R}^{2}$ & $\mathrm{M}$ & $\mathrm{R}^{2}$ & $\overline{\mathrm{m}}$ & $\mathrm{R}^{2}$ & $\bar{m}$ \\
\hline Ravine forest & 0.72 & 3.1 & 0.81 & 14.2 & 0.71 & 15.3 & 0.52 & 17.2 & 0.71 & $\overline{49.8}$ \\
\hline Slope forest & 0.42 & 5.1 & 0.62 & 13.0 & 0.85 & 43.7 & 0.57 & 97.1 & 0.76 & 159 \\
\hline Ridge forest & 0.92 & 7.8 & 0.89 & 21.7 & 0.53 & 75.8 & 0.69 & 67.0 & 0.74 & 172 \\
\hline
\end{tabular}

other neotropical montane sites (compare compilation by Freiberg \& Freiberg 2000). As expected, epiphytic biomass increased strongly with tree size. Hsu et al. (2002) found a linear relationship of epiphytic biomass with tree dbh. Our own biomass data, in contrast, showed a linear relationship with tree basal area or log-transformed dbh (data not shown; see Chen et al. 2010, Wolf et al. 2009 for corresponding results). Such would also be expected on theoretical grounds, since tree surface area is correlated more closely with basal area than with dbh (West et al. 1999).

Although the relationship between tree size and epiphyte load was similarly steep for ridge forest and slope forest (Figure 2), total epiphytic biomass of the former was lower due to the scarcity of large trees (biomass ridge: $4.4 \mathrm{Mg} \mathrm{ha}^{-1}$; slope: $6.3 \mathrm{Mg} \mathrm{ha}^{-1}$ ). However, these differences were not significant $(\mathrm{P}=0.06)$. Ravine forest, in contrast, had significantly and substantially lower epiphytic biomass $\left(2.6 \mathrm{t} \mathrm{ha}^{-1}\right)$ than stands on adjacent slopes, despite higher bark surface area available for epiphyte growth. We suggest that epiphyte growth in ravine forest is limited by low light availability as a consequence of extensive shading from the sheltered terrain position and a dense upper canopy. The low light levels in ravines and on lower slopes also promote the formation of straight trunks, which form poor-quality substrates for epiphytes. Moreover, the high tree turnover in this relatively productive forest type (Homeier 2004, Homeier et al. 2010) counteracts the accumulation of epiphytic matter (Tanner 1980). Differences in biomass along the topographic gradient were most pronounced with respect to DBM, which increased strongly from ravine forest through slope forest to ridge forest (Table 1).
This gradient is closely paralleled by DBM accumulation in the organic layer of terrestrial soil (Wolf et al. in press). In contrast, soil nutrient availability, litter quality and decomposition decrease from ravines to ridges (Homeier et al. 2010, Wolf et al. in press). This pattern suggests that the increasing accumulation of terrestrial DBM near ridges results from slow mineralization of poor-quality litter (Homeier \& Werner, unpubl. data), and the same may also apply to epiphytic DBM.

Although our sample size was large compared to most other studies on epiphytic biomass, our results are constrained by the inherently high spatial heterogeneity of epiphytic matter, even within branch classes of single forest types (Table 1). In particular, uncertainty arises from imperfect correlations between tree-size and biomass (Table 2) and resulting extrapolations (Table 3), but also from the visual estimation of bark surface area.

Our estimates for bryophyte maximum water storage capacity $(0.3-0.5 \mathrm{~mm})$ are substantially below those by Kürschner \& Parolly (2004) made for closely corresponding forest types in the same area (3.6-9.5 $\mathrm{mm}$ ). While maximum water storage capacities used for calculations are identical, and tree surface estimates very similar between the two studies, the bryophyte densities ( $\mathrm{g} \mathrm{m}^{-2}$ bark surface) of Kürschner \& Parolly (2004) are much higher than in our study. Our water storage estimates are also distinctly below those of mossy cloud forests in Puerto Rico (3.6-6.1 mm; Weaver 1972), Costa Rica (5.0-5.2 mm; Köhler et al. 2007, Tobón et al. 2010) or Tanzania (5.0 mm; Pócs 1980), but similar to a Costa Rican montane forest little affected by fog $(0.8 \mathrm{~mm}$; Hölscher et al. 2004).

Table 3. Tree basal area and estimates of epiphytic biomass $\left(\mathrm{kg} \mathrm{ha}^{-1}\right)$ across three adjacent forest types of south-east Ecuador, based on the regression slope of epiphytic biomass versus tree basal area (Table 2). Given is the mean \pm SD from six plots; the range of the $2.5-97.5 \%$ confidence interval of the estimate is added in parentheses. Different superscript letters indicate significant differences between forest types (ANOVA and Scheffé post hoc test; $\mathrm{P}<0.05$ ).

\begin{tabular}{lclllcc}
\hline & & \multicolumn{4}{c}{ Biomass $\left(\mathrm{kg} \mathrm{ha}^{-1}\right)$} \\
\cline { 3 - 6 } & Basal area $\left(\mathrm{m}^{2} \mathrm{ha}^{-1}\right)$ & \multicolumn{1}{c}{ Lichens } & Bryophytes & Vascular plants & Dead organic matter & Total biomass \\
\hline Ravine forest & $54.8^{\mathrm{a}} \pm 13.8$ & $162^{\mathrm{a}} \pm 43$ & $732^{\mathrm{a}} \pm 193$ & $126^{\mathrm{a}} \pm 33$ & $888^{\mathrm{a}} \pm 235$ & $2570^{\mathrm{a}} \pm 679$ \\
& & $(117-207)$ & $(569-895)$ & $(355-942)$ & $(509-1267)$ & $(1830-3310)$ \\
Slope forest & $39.5^{\mathrm{a}} \pm 6.2$ & $204^{\mathrm{a}} \pm 34$ & $520^{\mathrm{a}} \pm 87$ & $1174^{\mathrm{b}} \pm 9$ & $3877^{\mathrm{b}} \pm 647$ & $6346^{\mathrm{b}} \pm 1059$ \\
& & $\left(98^{-309)}\right.$ & $(337-703)$ & $(950-1399)$ & $(2367-5387)$ & $(4729-7963)$ \\
Ridge forest & $25.8^{\mathrm{b}} \pm 9$ & $200^{\mathrm{a}} \pm 70$ & $560^{\mathrm{a}} \pm 195$ & $1422^{\mathrm{b}} \pm 42$ & $1730^{\mathrm{a}} \pm 603$ & $4446^{\mathrm{b}} \pm 1550$ \\
& & $(173-228)$ & $(472-648)$ & $(823-2021)$ & $(1212-2247)$ & $(3265-5623)$ \\
\hline
\end{tabular}




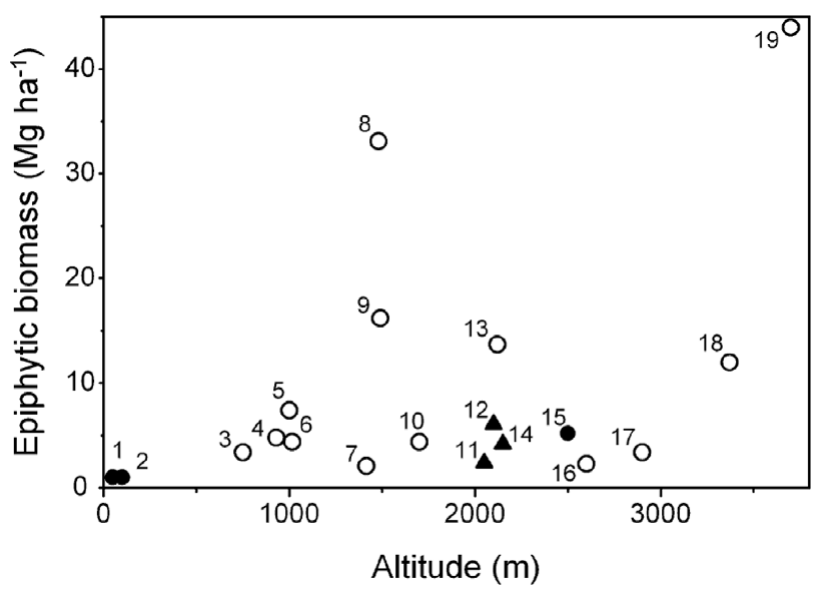

Figure 3. Total epiphytic biomass of mature tropical forests in relation to elevation. Open symbols: cloud forest sites, filled symbols: forests not regularly submersed in clouds. Data points representing the present study are shown as triangles. Omitted are studies that do not consider all major biomass components. Data points (region, mean canopy height $(\mathrm{m})$, mean annual precipitation $(\mathrm{m})$, reference) as follows: $1=$ east Brazil, 28, 3.0 (Mackensen et al. 2000); 2 = south Venezuela, 20, 3.6, (Klinge \& Herrera 1983); 3 = north-east Taiwan, 12, 3.6 (Hsu et al. 2002); $4=$ Puerto Rico (windward slope), 12, 5.3 (Weaver 1972); $5=$ Puerto Rico (leeward slope), 3, 5.3 (Weaver 1972); 6 = Puerto Rico (ridge top), 3, 5.3 (Weaver 1972); 7 = Tanzania, 40, 2.3 (Pócs 1980); $8=$ Costa Rica, 23, 3.2 (Nadkarni et al. 2004); 9 = Costa Rica, 24, 6.0 (Köhler et al. 2007); $10=$ Costa Rica, 10, 2.5 (Nadkarni 1984); $11=$ south-east Ecuador (ravine), 23, 2.1 (this study); $12=$ south-east Ecuador (slope), 14, 2.1 (this study); 13= Tanzania, 5, 3.0 (Pócs 1980); $14=$ south-east Ecuador (ridge), 9, 2.1 (this study); 15 = Papua New Guinea, 30, 4.0 (Edwards \& Grubb 1977); $16=$ south-west China, 6, 1.9 (Chen et al. 2010); 17 = Costa Rica, 33, 3.1 (Köhler 2002); $18=$ south Colombia, 22, 1.5 (Veneklaas et al. 1990); $19=$ south Colombia, 13, 1.3 (Hofstede et al. 1993).

\section{Transregional context}

Our epiphytic biomass values are within the lower range of other moist montane tropical sites (Figure 3), showing that high diversity of epiphytes (Liede \& Breckle 2007, Nöske et al. 2008) is not necessarily coupled with high epiphyte biomass density. Multiple regression analysis of potential epiphytic biomass predictors available for the studies compared in Figure 3 (elevation, stand height, precipitation, an index of aridity (precipitation/potential evapotranspiration), incidence of fog) did not yield a significant model (results not shown). Clearly, the available number of studies from tropical forests remains too low to untangle a complex set of predictors. Particularly scarce are data from the Old World, moist lowland forests, montane forests other than cloud forests, and seasonally dry woodlands as a whole. Nonetheless, the data suggest a key role of moisture availability. Epiphytic biomass at our site was similar to another study from a montane non-cloud forest (Edwards \& Grubb 1977), whereas several forests frequently submersed in clouds greatly exceeded these values, confirming that regular fog can boost epiphytic biomass (Figure 3). Humidity is widely considered a key predictor for the development of epiphyte communities in temperate (Díaz et al. 2010, McCune 1993) and tropical forests (Kreft et al. 2004, Werner \& Gradstein 2009; see also Tanner 1980, Weaver 1972). However, while a general positive effect of moisture on epiphytic biomass accumulation is reasonably evident, the influence of sheer quantity, quality and seasonality of water input and periods of drought remains unclear. Several of the study sites shown in Figure 3 even lack basic information on the seasonality of rainfall, and the contributions of wind-driven rain and fog to overall water inputs are unknown but for few sites. More case studies on epiphytic biomass, especially in conjunction with sound climate data, will help in understanding how epiphytic biomass is distributed across tropical landscapes and how it will respond to global climate change.

\section{Conclusions}

Our study shows that three sources of heterogeneity (branch diameter, tree size, topographic position and resulting differences in stand structure) strongly affect quantity and quality of epiphytic biomass in tropical forests. The significant differences in amount and composition of epiphytic matter between adjacent forest types have general implications for resource availability to other canopy biota, and the cycling of water and nutrients. Although our study could not differentiate between direct effects of slope position (nutrient availability, mesoclimate) and indirect effects (stand structure and dynamics), it provides evidence that fine-scale topography needs to be taken into account when extrapolating epiphytic biomass and related matter fluxes from standlevel data to regional scale.

\section{ACKNOWLEDGEMENTS}

We thank Ute Knörr, Daniela Sellbrink and Fabian Schröder for their excellent help with field and laboratory work, and Sven Günter for the good cooperation. Lars Köhler, Tamás Pócs, Ed Tanner and Pete Weaver provided valuable additional information on their studies. Comments by Sampurno Bruijnzeel significantly improved the manuscript. Funding was provided by the Deutsche Forschungsgemeinschaft (DFG) within the framework of research unit FOR 402. FAW acknowledges a PhD scholarship by the German Academic Exchange Service (DAAD) and a grant from IdeaWild. This is publication no. 257 of the Yanayacu Natural History Research Group. 


\section{LITERATURE CITED}

BELLINGHAM, P. J. \& TANNER, E. V. J. 2000. The influence of topography on tree growth, mortality, and recruitment in a tropical montane forest. Biotropica 32:378-384.

BENDIX, J., ROLLENBECK, R., RICHTER, M., FABIAN, P. \& EMCK, P. 2008. Climate. Pp. 63-73 in Beck, E., Bendix, J., Kottke, I., Makeschin, F. \& Mosandl, R. (eds.). Gradients in a tropical mountain ecosystem of Ecuador. Springer, Berlin.

BENJAMINI, Y. \& HOCHBERG, Y. 1995. Controlling the false discovery rate: a practical and powerful approach to multiple testing. Journal of the Royal Statistical Society B 57:289-300.

BIRCH, H. F. \& FRIEND, M. T. 1956. The organic-matter and nitrogen status of East African soils. Journal of Soil Science 7:156-167.

BRUIJNZEEL, L. A., MULLIGAN, M. \& SCATENA, F. N. 2011. Hydrometeorology of tropical montane cloud forests: emerging patterns. Hydrological Processes 25:465-498.

CAVELIER, J., JARAMILLO, M., SOLIS, D. \& DE LEON, D. 1997. Water balance and nutrient inputs in bulk precipitation in tropical montane cloud forest in Panama. Journal of Hydrology 193:83-96.

CHEN, L., LIU, W. Y. \& WANG, G. S. 2010. Estimation of epiphytic biomass and nutrient pools in the subtropical montane cloud forest in the Ailao Mountains, south-western China. Ecological Research 25:315-325.

DÍAZ, I. A., SIEVING, K. E., PEÑA-FOXON, M. E., LARRAÍN, J. \& ARMESTO, J. J. 2010. Epiphyte diversity and biomass loads of canopy emergent trees in Chilean temperate rain forests: a neglected functional component. Forest Ecology and Management 259:14901501.

DUDGEON, W. 1923. Succession of epiphytes in the Quercus incana forest at Landour, western Himalayas. Preliminary notes. Journal of the Indian Botanical Society 3:270-272.

EDWARDS, P. J. \& GRUBB, P. J. 1977. Studies of mineral cycling in a montane rainforest in New Guinea I. The distribution of organic matter in the vegetation and soil. Journal of Ecology 65:943-969.

EMCK, P. 2007. A climatology of South Ecuador. Ph.D. thesis, FriedrichAlexander-Universität, Erlangen. 275 pp.

FREIBERG, M. \& FREIBERG, E. 2000. Epiphyte diversity and biomass in the canopy of lowland and montane forests in Ecuador. Journal of Tropical Ecology 16:673-688.

GENTRY, A. H. \& DODSON, C. H. 1987. Diversity and biogeography of neotropical vascular epiphytes. Annals of the Missouri Botanical Garden 74:205-233.

GÜNTER, S., CABRERA, O., WEBER, M., STIMM, B., ZIMMERMANN, M., FIEDLER, K., KNUTH, J., BOY, J., WILCKE, W., IOST, S., MAKESCHIN, F., WERNER, F. A., GRADSTEIN, S. R. \& MOSANDL, R. 2008. Natural forest management in neotropical mountain rain forests an ecological experiment. Pp. 363-376 in Beck, E., Bendix, J., Kottke, I., Makeschin, F. \& Mosandl, R. (eds.). Gradients in a tropical mountain ecosystem of Ecuador. Springer, Berlin.

HOFSTEDE, R. G. M., WOLF, J. H. D. \& BENZING, D. H. 1993. Epiphytic biomass and nutrient status of a Colombian upper montane rain forest. Selbyana 14:37-45.

HÖLSCHER, D., KÖHLER, L., VAN DIJK, A. \& BRUIJNZEEL, L. A. 2004. The importance of epiphytes to total rainfall interception by a tropical montane rain forest in Costa Rica. Journal of Hydrology 292:308322.

HOLWERDA, F., BRUIJNZEEL, L. A., MUNOZ-VILLERS, L. E., EQUIHUA, M. \& ASBJORNSEN, H. 2010. Rainfall and cloud water interception in mature and secondary lower montane cloud forests of central Veracruz, Mexico. Journal of Hydrology 384:84-96.

HOMEIER, J. 2004. Baumdiversität, Waldstruktur und Wachstumsdynamik zweier tropischer Bergregenwälder in Ecuador und Costa Rica. Dissertationes Botanicae 391:1-181.

HOMEIER, J., WERNER, F. A., GRADSTEIN, S. R., BRECKLE, S.-W. \& RICHTER, M. 2008. Potential vegetation and floristic composition of Andean forests in South Ecuador, with a focus on the RBSF. Pp. 87-100 in Beck, E., Bendix, J., Kottke, I., Makeschin, F. \& Mosandl, R. (eds.). Gradients in a tropical mountain ecosystem of Ecuador. Springer, Berlin.

HOMEIER, J., BRECKLE, S.-W., GÜNTER, S., ROLLENBECK, R. T. \& LEUSCHNER, C. 2010. Tree diversity, forest structure and productivity along altitudinal and topographical gradients in a species-rich Ecuadorian montane rain forest. Biotropica 42:140-148.

HSU, C.-C., HORNG, F.-W. \& KUO, C.-M. 2002. Epiphyte biomass and nutrient capital of a moist subtropical forest in north-eastern Taiwan. Journal of Tropical Ecology 18:659-670.

KLINGE, H. \& HERRERA, R. 1983. Phytomass structure of natural plant communities on spodosols in southern Venezuela: the tall Amazon caatinga forest. Vegetatio 53:65-84.

KÖHLER, L. 2002. Die Bedeutung der Epiphyten im ökosystemaren Wasserund Nährstoffumsatz verschiedener Altersstadien eines Bergregenwaldes in Costa Rica. Ph.D. thesis, Georg-August-Universität, Göttingen. 152 pp.

KÖHLER, L., TOBÓN, C., FRUMAU, K. F. A. \& BRUIJNZEEL, L. A. S. 2007. Biomass and water storage dynamics of epiphytes in old-growth and secondary montane cloud forest stands in Costa Rica. Plant Ecology 193:171-184.

KREFT, H., KÖSTER, N., KÜPER, W., NIEDER, J. \& BARTHLOTT, W. 2004. Diversity and biogeography of vascular epiphytes in Western Amazonia, Yasuní, Ecuador. Journal of Biogeography 31:1463-1476.

KÜRSCHNER, H. \& PAROLLY, G. 2004. Phytomass and water storage capacity of epiphytic rainforest bryophyte communities in S Ecuador. Botanische Jahrbücher für Systematik, Pflanzengeschichte und Pflanzengeographie 125:489-504.

LIEDE, S. \& BRECKLE, S.-W. (eds.) 2007. Provisional checklists of flora and fauna of the San Francisco valley and its surroundings (Estación Cientifica San Francisco, Prov. Zamora-Chinchipe, Southern Ecuador). Ecotropical Monographs 4. Gesellschaft für Tropenökologie, Bonn. 256 pp.

MACKENSEN, J., TILLERY-STEVENS, M., KLINGE, R. \& FÖLSTER, H. 2000. Site parameters, species composition, phytomass structure and element stores of a terra-firme forest in East-Amazonia, Brazil. Plant Ecology 151:101-119.

MCCUNE, B. 1993. Gradients in epiphyte biomass in three PseudotsugaTsuga forests of different ages in western Oregon and Washington. Bryologist 96:405-411.

MOTZER, T. 2005. Micrometeorological aspects of a tropical mountain forest. Agricultural and Forest Meteorology 135:230-240.

NADKARNI, N. M. 1984. Epiphyte biomass and nutrient capital of a neotropical elfin forest. Biotropica 16:249-256. 
NADKARNI, N. M. 2000. Colonization of stripped branch surfaces by epiphytes in a lower montane cloud forest, Monteverde, Costa Rica. Biotropica 32:358-363.

NADKARNI, N. M., SCHAEFER, D., MATELSON, T. J. \& SOLANO, R. 2004. Biomass and nutrient pools of canopy and terrestrial components in a primary and a secondary montane cloud forest, Costa Rica. Forest Ecology and Management 198:223-236.

NÖSKE, N. M., HILT, N., WERNER, F. A., BREHM, G., FIEDLER, K., SIPMAN, H. J. M. \& GRADSTEIN, S. R. 2008. Disturbance effects on diversity of epiphytes and moths in a montane forest in Ecuador. Basic and Applied Ecology 9:4-12.

OESKER, M., DALITZ, H., GÜNTHER, S., HOMEIER, J. \& MATEZKI, S. 2008. Spatial heterogeneity patterns - a comparison between ravines and crests in the upper part of a evergreen lower montane forest. Pp. 267-274 in Beck, E., Bendix, J., Kottke, I., Makeschin, F. \& Mosandl, R. (eds.). Gradients in a tropical mountain ecosystem of Ecuador. Springer, Berlin.

OESKER, M., DALITZ, H., HOMEIER, J. \& BRUIJNZEEL, L. A. 2010. Spatial heterogeneity of canopy throughfall quantity and quality in a tropical mountain forest in South Ecuador. Pp. 391-401 in Bruijnzeel, L. A., Scatena, F. N. \& Hamilton, L. S. (eds.). Tropical montane cloud forests: science for conservation and management. Cambridge University Press, Cambridge.

PÓCS, T. 1980. The epiphytic biomass and its effect on the water balance of two rain forest types in the Uluguru Mountains (Tanzania, East Africa). Acta Botanica Academiae Scientiarium Hungaricae 26:143167.

SIPMAN, H. J. M. \& HARRIS, R. C. 1989. Lichens. Pp. 303-309 in Lieth, H. \& Werger, M. J. A. (eds.). Tropical rain forest ecosystems (biogeographical and ecological studies). Elsevier, Amsterdam.

TAKUYA, M., AIBA, S.-I. \& KITAYAMA, K. 2002. Effects of topography on tropical lower montane forests under different geological conditions on Mount Kinabalu, Borneo. Plant Ecology 159:35-49.

TANNER, E. V. J. 1980. Studies on the biomass and productivity in a series of montane rain forests in Jamaica. Journal of Ecology 68:573588.

TOBÓN, C., KÖHLER, L., FRUMAU, K. F. A., BRUIJNZEeL, L. A., BURKARD, R. \& SCHMID, S. 2010. Water dynamics of epiphytic vegetation in a lower montane cloud forest: fog interception, storage, and evaporation. Pp. 261-267 in Bruijnzeel, L. A., Scatena,
F. N. \& Hamilton, L. S. (eds.). Tropical montane cloud forests: science for conservation and management. Cambridge University Press, Cambridge.

UMANA, N. H. N. \& WANEK, W. 2010. Large canopy exchange fluxes of inorganic and organic nitrogen and preferential retention of nitrogen by epiphytes in a tropical lowland rainforest. Ecosystems 13:367381.

VENEKLAAS, E. J., ZAGT, R. J., VAN LEERDAM, A., VAN EK, R., BROEKHOVEN, A. J. \& VAN GENDEREN, M. 1990. Hydrological properties of the epiphyte mass of a montane tropical rain forest, Colombia. Vegetatio 89:183-192.

WEAVER, P. L. 1972. Cloud moisture interception in the Luquillo Mountains of Puerto Rico. Caribbean Journal of Science 12:129144.

WERNER, F. A. \& GRADSTEIN, S. R. 2009. Diversity of dry forest epiphytes along a gradient of human disturbance in the tropical Andes. Journal of Vegetation Science 20:59-68.

WEST, B. G., BROWN, J. H. \& ENQUIST, B. J. 1999. A general model for the structure and allometry of plant vascular systems. Nature 400:664-667.

WILCKE, W., OELMANN, Y., SCHMITT, A., VALAREZO, C., ZECH, W. \& HOMEIER, J. 2008. Soil properties and tree growth along an altitudinal transect in Ecuadorian tropical montane forest. Journal of Plant Nutrition and Soil Science 171:220-230.

WOLF, J. H. D. 1995. Diversity patterns and biomass of epiphytic bryophytes and lichens along an altitudinal gradient in the northern Andes. Annals of the Missouri Botanical Garden 80:928-960.

WOLF, J. H. D., GRADSTEIN, S. R. \& NADKARNI, N. M. 2009. A protocol for sampling vascular epiphyte richness and abundance. Journal of Tropical Ecology 25:107-121.

WOLF, K., VELDKAMP, E., HOMEIER, J., FLESSA, H. \& MARTINSON, G. In press. Nitrogen availability links forest productivity, soil nitrous oxide and nitric oxide fluxes of a tropical montane forest in southern Ecuador. Global Biogeochemical Cycles.

ZIMMERMANN, A., WILCKE, W. \& ELSENBEER, H. 2007. Spatial and temporal patterns of throughfall quantity and quality in a tropical montane forest in Ecuador. Journal of Hydrology 343:80-96.

ZOTZ, G. \& VOLLRATH, B. 2003. The epiphyte vegetation of the palm, Socratea exorrhiza-correlations with tree size, tree age, and bryophyte cover. Journal of Tropical Ecology 19:81-90. 
Appendix 1.Host trees sampled for epiphytic biomass in three adjacent forest types in montane south-east Ecuador.

\begin{tabular}{|c|c|c|c|c|}
\hline Forest type & Species & Family & $\mathrm{dbh}(\mathrm{cm})$ & Stratum \\
\hline Ravine & Meriania franciscana C. Ulloa \& Homeier & Melastomataceae & 64.5 & Canopy \\
\hline Ravine & Guarea cf. & Meliaceae & 58.3 & Canopy \\
\hline Ravine & Tabebuia chrysantha (Jacq.) G. Nicholson & Bignoniaceae & 45.7 & Canopy \\
\hline Ravine & Hieronyma asperifolia Pax \& K. Hoffm. & Euphorbiaceae & 45.4 & Canopy \\
\hline Ravine & Nectandra cf. membranacea (Sw.) Griseb. & Lauraceae & 38.2 & Canopy \\
\hline Ravine & Eleagia utilis (Goudot) Wedd. & Rubiaceae & 37.9 & Canopy \\
\hline Ravine & Heliocarpus americanus L. & Tiliaceae & 37.1 & Canopy \\
\hline Ravine & Cecropia andina Cuatrec. & Cecropiaceae & 36.1 & Canopy \\
\hline Ravine & Sapium glandulosum (L.) Morong & Euphorbiaceae & 31.8 & Canopy \\
\hline Ravine & Cedrela montana Moritz ex Turcz. & Meliaceae & 28.0 & Canopy \\
\hline Ravine & Turpinia occidentalis (Sw.) G. Don & Staphyleaceae & 25.6 & Canopy \\
\hline Ravine & Trichilia cf. & Meliaceae & 24.5 & Canopy \\
\hline Ravine & Allophylus floribundus (Poepp.) Radlk. & Sapindaceae & 22.9 & Canopy \\
\hline Ravine & Ficus pertusa L.f. & Moraceae & 20.8 & Canopy \\
\hline Ravine & Talauma sp. & Magnoliaceae & 20.1 & Canopy \\
\hline Ravine & Solanum nutans Ruiz \& Pav. & Solanaceae & 14.6 & Understorey \\
\hline Ravine & Inga cf. acuminata Benth. & Mimosaceae & 12.4 & Understorey \\
\hline Ravine & Boehmeria caudata Sw. & Urticaceae & 10.5 & Understorey \\
\hline Ravine & Alsophila mostellaria M. Lehnert & Cyatheaceae & 5.7 & Understorey \\
\hline Ravine & Psychotria tinctoria Ruiz \& Pav. & Rubiaceae & 3.0 & Understorey \\
\hline Ravine & Hieronyma asperifolia Pax \& K. Hoffm. & Euphorbiaceae & 1.4 & Understorey \\
\hline Slope & Alzatea verticillata Ruiz \& Pav. & Alzateaceae & 41.4 & Canopy \\
\hline Slope & Clusia sp. (sect. Anandrogyne) & Clusiaceae & 35.7 & Canopy \\
\hline Slope & Alzatea verticillata Ruiz \& Pav. & Alzateaceae & 33.7 & Canopy \\
\hline Slope & Myrcia sp. nov. & Myrtaceae & 24.6 & Canopy \\
\hline Slope & Cupania sp. & Sapindaceae & 22.0 & Canopy \\
\hline Slope & Hieronyma moritziana (Müll. Arg.) Pax \& K. Hoffm. & Euphorbiaceae & 21.3 & Canopy \\
\hline Slope & Myrcia sp. nov. & Myrtaceae & 19.2 & Canopy \\
\hline Slope & Ocotea cf. aciphylla (Nees) Mez & Lauraceae & 19.1 & Canopy \\
\hline Slope & Alchornea grandiflora Müll. Arg. & Euphorbiaceae & 18.8 & Canopy \\
\hline Slope & Ocotea cf. benthamiana $\mathrm{Mez}$ & Lauraceae & 16.6 & Canopy \\
\hline Slope & Schefflera sp. & Araliaceae & 15.0 & Canopy \\
\hline Slope & Graffenrieda emarginata (Ruiz \& Pav.) Triana & Melastomataceae & 13.4 & Canopy \\
\hline Slope & Clusia ducuoides Engl. & Clusiaceae & 12.2 & Canopy \\
\hline Slope & Symplocos bogotensis Brand & Symplocaceae & 11.6 & Canopy \\
\hline Slope & Elaeagia pastoense L.E. Mora & Rubiaceae & 8.0 & Canopy \\
\hline Slope & Graffenrieda harlingii Wurdack & Melastomataceae & 6.1 & Understorey \\
\hline Slope & Prunus opaca (Benth.) Walp. & Rosaceae & 5.1 & Understorey \\
\hline Slope & Eschweilera sessilis A.C. Sm. & Lecythidaceae & 4.4 & Understorey \\
\hline Slope & Stilpnophyllum oellgaardii L. Andersson & Rubiaceae & 2.2 & Understorey \\
\hline Slope & Miconia sp. & Melastomataceae & 2.0 & Understorey \\
\hline Slope & Myrsine cf. & Myrsinaceae & 0.8 & Understorey \\
\hline Ridge & Alchornea grandiflora Müll. Arg. & Euphorbiaceae & 31.9 & Canopy \\
\hline Ridge & Purdiaea nutans Planch. & Clethraceae & 26.4 & Canopy \\
\hline Ridge & Alchornea grandiflora Müll. Arg. & Euphorbiaceae & 24.9 & Canopy \\
\hline Ridge & Purdiaea nutans Planch. & Clethraceae & 22.6 & Canopy \\
\hline Ridge & Graffenrieda emarginata (Ruiz \& Pav.) Triana & Melastomataceae & 19.8 & Canopy \\
\hline Ridge & Calyptranthes pulchella DC. & Myrtaceae & 18.5 & Canopy \\
\hline Ridge & Graffenrieda emarginata (Ruiz \& Pav.) Triana & Melastomataceae & 17.5 & Canopy \\
\hline Ridge & Podocarpus oleifolius D. Don ex Lamb. & Podocarpaceae & 14.4 & Canopy \\
\hline Ridge & Clusia ducu Benth. & Clusiaceae & 12.1 & Canopy \\
\hline Ridge & Persea subcordata (Ruiz \& Pav.) Nees & Lauraceae & 11.5 & Canopy \\
\hline Ridge & Podocarpus oleifolius D. Don ex Lamb. & Podocarpaceae & 9.9 & Canopy \\
\hline Ridge & Graffenrieda harlingii Wurdack & Melastomataceae & 9.5 & Canopy \\
\hline Ridge & Clusia ducu Benth. & Clusiaceae & 8.9 & Canopy \\
\hline Ridge & Weinmannia elliptica Kunth & Cunoniaceae & 8.6 & Canopy \\
\hline Ridge & Myrcia sp. nov. & Myrtaceae & 8.2 & Canopy \\
\hline Ridge & Alzatea verticillata Ruiz \& Pav. & Alzateaceae & 7.3 & Understorey \\
\hline Ridge & Hedyosmum anisodorum Todzia & Chloranthaceae & 7.0 & Understorey \\
\hline Ridge & Licaria subsessilis van der Werff & Lauraceae & 6.1 & Understorey \\
\hline Ridge & Weinmannia ovata Cav. & Cunoniaceae & 3.0 & Understorey \\
\hline Ridge & Cyathea bipinnatifida (Baker) Domin & Cyatheaceae & 2.5 & Understorey \\
\hline Ridge & Ilex sp. & Aquifoliaceae & 1.1 & Understorey \\
\hline
\end{tabular}

